\title{
Occurrence and variation of calcium oxalate crystals in selected medicinal plant species
}

\author{
Alyssa Faye Z. Capacio and Beatriz S. Belonias*
}

\begin{abstract}
Calcium oxalate ( $\mathrm{CaOx}$ ) crystals are microscopic mineralized particles found in over 215 plant families of plants. In this study, the occurrence and variation of $\mathrm{CaOx}$ crystals in 15 different species of commonly used medicinal plants were investigated. Information on the type and other characteristics of CaOx crystals present in medicinal plants is important considering the potential health risks posed by these crystals to humans and other animals, aside from the fact that crystal characteristics are also valuable in the taxonomic identification of plant taxa. Results showed that eight of the 15 species, namely; Abelmoschus esculentus, Acalypha indica, Amaranthus viridis, Basella alba, Bixa orellana, Codiaeum variegatum, Ipomoea batatas, and Jatropha podagrica produced druses. Only four species formed raphides and these were Bougainvillea spectabilis, Cordyline fruticosa, Impatiens balsamina, and Rhoeo spathacea, although styloids were also observed in Cordyline fruticosa. Prismatic crystals and crystal sands were the least common, the former produced only in Chorchorus olitorius and Senna alata, and the latter only in Solanum melongena. The raphides of $B$. spectabilis were the longest at $175.81 \mu \mathrm{m}$ while the druses of $B$. orellana were the smallest having a mean diameter of $16.72 \mu \mathrm{m}$. In terms of density, $C$. olitorius and $S$. alata had the highest number of crystals per unit leaf area.
\end{abstract}

Keywords: calcium oxalate crystals, raphides, druses, styloids, prismatic crystals, crystal sands, medicinal plants

\section{INTRODUCTION}

Calcium oxalate ( $\mathrm{CaOx}$ ) crystals are non-protoplasmic or ergastic bodies found in over 215 families of plants (Meric 2009a, Zhang et al 2014). In higher plants, these crystals typically form in the vacuoles, or to a lesser degree in seed storage

Department of Biological Sciences, Visayas State University 6521-A, Visca, Baybay City, Leyte

\footnotetext{
* Corresponding Author. Address: Department of Biological Sciences, Visayas State University 6521-A, Visca, Baybay City, Leyte; Email: beatrizbelonias@vsu.edu.ph

DOI: 10.32945/atr4024.2018
} 
protein bodies, or within or on the outer surface of cell walls (Ilarsan et al 1997). In angiosperms, they form inside vacuoles while in gymnosperms, most of the crystals form in the cell wall (Konyar et al 2014). CaOx crystals are more common in leaves than in stems (Meric 2009a) and are often found in the epidermal, mesophyll and vascular tissues (He et al 2011). The common $\mathrm{CaOx}$ crystal types based on morphology are the raphides, druses, prismatic crystals, styloids and crystal sands (llarsan et al 1997, Zhang et al 2014).

The shape, location, and hydration forms of $\mathrm{CaOx}$ crystals are specific to a species and are developmentally determined by the type of cell, tissue, and organ in which they occur. Because of this, they have been used in the taxonomic classification and identification in a number of plant taxa (Flores 2001). They also play a role against herbivory by deterring chewing insects, birds and other grazing animals (Ruiz et al 2002).

These crystals have a very important diagnostic value in medicinal plants (Odufuwa et al 2014). They are important in the detection and identification of adulterants in crude drugs. They also increase the antioxidant property of some medicinal plants apart from their being useful in the treatment of fractures and bone ailments (Anitha \& Sandhiya 2014). However, there are also increasing reports that consumption of large doses of $\mathrm{CaOx}$ crystals in animals may induce formation of renal stones by forming precipitates around renal tubules. Physiologically, high oxalate content may raise the risk of urinary stones by sequestering calcium which is one of the essential ions required for osmoregulation. Moreover, sharp crystals of oxalate have been reported to cause injury to body tissue and also induce inflammation (Odufuwa et al 2014). In worst case scenario, these can cause poisoning that can lead to death (Knight \& Walter 2003).

Considering the aforementioned potential health risks of consumption of $\mathrm{CaOx}$ crystals, it is crucial that the crystal content of medicinal plants be determined and characterized in order to ensure their safe use, especially for commonly used species which are usually consumed or taken internally. Furthermore, a thorough characterization of the morphological types, density and distribution of these crystals in different plant species would be a valuable addition to our present knowledge of plant structure and their application in plant identification.

In this study, the $\mathrm{CaOx}$ crystals in fifteen medicinal plant species were characterized, giving priority to those that are widely used in the Philippines. Specifically, it was done to compare the type of calcium oxalate (CaOx) crystals present in common medicinal plant species, characterize the type of $\mathrm{CaOx}$ crystals present in these species, and compare their size, density and distribution in different regions of the leaf lamina.

\section{MATERIALS AND METHODS}

\section{Collection of Leaf Samples}

Two fresh, mature and fully expanded leaves from three individual plants of each of the 15 species of medicinal plants were randomly handpicked from plants growing in gardens or in their natural habitat within Baybay City, Leyte. These medicinal plant species include Abelmoschus esculentus (L.) Moench (Malvaceae), Acalypha indica L.(Euphorbiaceae), Amaranthus viridis L. 
Occurrence and variation of calcium oxalate crystals

(Amaranthaceae), Basella alba L. (Basellaceae), Bixa orellana L. (Bixaceae), Bougainvillea spectabilis (Nyctaginaceae), Chorchorus olitorius L. (Tiliaceae), Codiaeum variegatum (L.) A. Juss. (Euphorbiaceae), Cordyline fruticosa (L.) A. Chev. (Asparagaceae), Impatiens balsamina L. (Balsaminaceae), Ipomoea batatas (L.) Lam. (Convolvulaceae), Jatropha podagrica Hook (Euphorbiaceae), Rhoeo spathacea (Sw.) Stearn (Commelinaceae), Senna alata (L.) Roxb., (Fabaceae), and Solanum melongena $\mathrm{L}$. (Solanaceae). These species were chosen because they are among the most commonly used medicinal plants in the Philippines. Some of these species are shown in Figure 1A-F. Some of the medicinal uses of the selected species are shown in Table 1.

Leaf samples were gathered from healthy plants, washed to remove dirt and then placed in a bucket with ice to maintain freshness. Ten circular discs were randomly taken from each leaf, five along the midvein and the other five along the margin using a single hole paper puncher. The sample leaf discs were placed in test tubes containing $3 \mathrm{~mL} 5 \%$ sodium hydroxide and allowed to soak overnight.

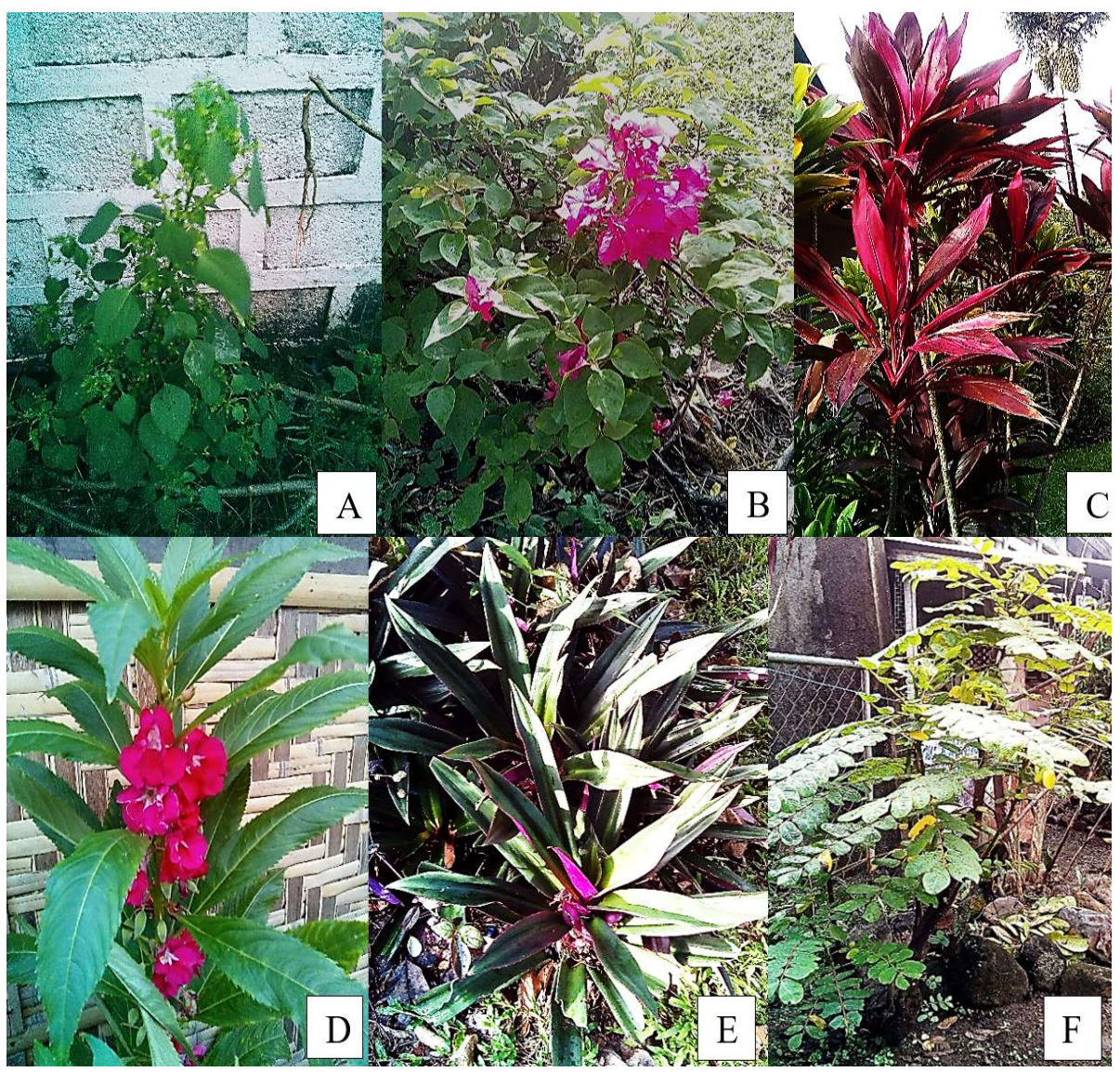

Figure 1A-F. Some of the medicinal plant species used in the study. A. Acalypha indica, B. Bougainvillea spectabilis, C. Cordyline fruticosa, D. Impatiens balsamina, E. Rhoeo spathacea, F. Senna alata 
Table 1. Some of the medicinal uses of the plant species studied

\begin{tabular}{|c|c|c|c|}
\hline Species & $\begin{array}{l}\text { English/ } \\
\text { Local Name }\end{array}$ & Medicinal Use & Reference \\
\hline $\begin{array}{l}\text { Abelmoschu } \\
\text { s esculentus } \\
\text { (L.) Moench }\end{array}$ & $\begin{array}{l}\text { Lady finger, } \\
\text { Okra }\end{array}$ & $\begin{array}{l}\text { The leaves are used as emollient and poultice } \\
\text { and mucilage from the roots and leaves is } \\
\text { used to treat gonorrhea. It has also } \\
\text { anticomplementary, anti-inflamatory and anti- } \\
\text { diabetic properties and can cure gastric } \\
\text { problems. }\end{array}$ & $\begin{array}{l}\text { Quisumbing, } \\
1978 . \\
\text { Tomoda et al, } \\
1989 \\
\text { Lengsfeld et al, } \\
2004\end{array}$ \\
\hline $\begin{array}{l}\text { Acalypha } \\
\text { indica L. }\end{array}$ & $\begin{array}{l}\text { Indian } \\
\text { Acalypha, } \\
\text { Bugos }\end{array}$ & $\begin{array}{l}\text { Anthelmintic when mixed with garlic. The } \\
\text { juice of the leaves is used to treat cough, } \\
\text { bronchitis and asthma. }\end{array}$ & $\begin{array}{l}\text { Quisumbing, } \\
1978\end{array}$ \\
\hline $\begin{array}{l}\text { Amaranthus } \\
\text { viridis L. }\end{array}$ & $\begin{array}{l}\text { Slender } \\
\text { Amaranth, } \\
\text { Kulitis }\end{array}$ & $\begin{array}{l}\text { The leaves are directly used to eczema, } \\
\text { psoriasis and rashes. It is also used as anti- } \\
\text { inflammatory agent of the urinary tract, } \\
\text { diuretic, venereal disease vermifuge, } \\
\text { analgestic, anti-rheumatic, antiulcer, laxative, } \\
\text { antileprotic, anti-asthma, and to treat eye } \\
\text { problems. }\end{array}$ & $\begin{array}{l}\text { Reyad-ul- } \\
\text { Ferdous, } 2015\end{array}$ \\
\hline $\begin{array}{l}\text { Basella } \\
\text { alba L. }\end{array}$ & $\begin{array}{l}\text { Malabar } \\
\text { Spinach, } \\
\text { Alugbati }\end{array}$ & $\begin{array}{l}\text { The mucilage from the leaves is a remedy for } \\
\text { headache. The decoction from the leaves is a } \\
\text { good laxative for children and pregnant } \\
\text { women. }\end{array}$ & $\begin{array}{l}\text { Kurian, 2010; } \\
\text { Quisumbing, } \\
1978\end{array}$ \\
\hline $\begin{array}{l}\text { Bixa } \\
\text { orellana L. }\end{array}$ & $\begin{array}{l}\text { Annato, } \\
\text { Achuete }\end{array}$ & $\begin{array}{l}\text { The decoction of the leaves is used to cure } \\
\text { skin diseases and burns and the leaf infusion } \\
\text { is prescribed as a purgative and in the } \\
\text { treatment of dysentery. }\end{array}$ & $\begin{array}{l}\text { Deshmukh et } \\
\text { al, } 2013\end{array}$ \\
\hline $\begin{array}{l}\text { Bougainvillea } \\
\text { spectabilis } \\
\text { Wild. }\end{array}$ & $\begin{array}{l}\text { Bougainvilla } \\
\text {, Bombil }\end{array}$ & $\begin{array}{l}\text { The leaves have antibacterial and anti- } \\
\text { diabetic properties. }\end{array}$ & $\begin{array}{l}\text { Umamaheswari } \\
\text { et al, } 2008 \\
\text { Neelesh et al, } \\
2010\end{array}$ \\
\hline $\begin{array}{l}\text { Chorchorus } \\
\text { olitorius L. }\end{array}$ & $\begin{array}{l}\text { Jute } \\
\text { Mallow, } \\
\text { Saluyot }\end{array}$ & $\begin{array}{l}\text { Tea made from dried leaves is used to treat } \\
\text { liver disorder. Cold infusion of the dried } \\
\text { leaves is used to treat acute dysentery. }\end{array}$ & $\begin{array}{l}\text { Quisumbing, } \\
1978\end{array}$ \\
\hline $\begin{array}{l}\text { Codiaeum } \\
\text { variegatum } \\
\text { (L.) A. Juss. }\end{array}$ & $\begin{array}{l}\text { Croton, } \\
\text { San } \\
\text { Francisco }\end{array}$ & $\begin{array}{l}\text { The sap from the leaves is used to treat } \\
\text { snakebites by drinking and rubbing it into the } \\
\text { bite. }\end{array}$ & $\begin{array}{l}\text { Motaleb et al, } \\
2011\end{array}$ \\
\hline $\begin{array}{l}\text { Cordyline } \\
\text { fruticosa (L.) } \\
\text { A. Chev. }\end{array}$ & $\begin{array}{l}\text { Baston de } \\
\text { San Jose, } \\
\text { Ti Plant }\end{array}$ & $\begin{array}{l}\text { The decoction of the leaves is administered } \\
\text { for dysentery. }\end{array}$ & $\begin{array}{l}\text { Quisumbing, } \\
1978\end{array}$ \\
\hline $\begin{array}{l}\text { Impatiens } \\
\text { balsamina L }\end{array}$ & $\begin{array}{l}\text { Rose } \\
\text { Balsam, } \\
\text { Kamantigue }\end{array}$ & $\begin{array}{l}\text { The pounded leaves are used in poultices to } \\
\text { dissolve felons. }\end{array}$ & $\begin{array}{l}\text { Quisumbing, } \\
1978\end{array}$ \\
\hline $\begin{array}{l}\text { Ipomoea } \\
\text { batatas (L.) } \\
\text { Lam. }\end{array}$ & $\begin{array}{l}\text { Sweetpotat } \\
\text { o, } \\
\text { Camote }\end{array}$ & $\begin{array}{l}\text { The leaves are used to cure diabetes, } \\
\text { hookworm, haemorrhage and abscesses. }\end{array}$ & Lim, 2016 \\
\hline
\end{tabular}


Occurrence and variation of calcium oxalate crystals

Table 1 Continuation

\begin{tabular}{|c|c|c|c|}
\hline Species & $\begin{array}{l}\text { English/ } \\
\text { Local Name }\end{array}$ & Medicinal Use & Reference \\
\hline $\begin{array}{l}\text { Jatropha } \\
\text { podagrica } \\
\text { Hook. }\end{array}$ & $\begin{array}{l}\text { Gout Plant, } \\
\text { Buddha } \\
\text { Belly Plant }\end{array}$ & $\begin{array}{l}\text { The decoction of the fruit, leaf and flower is } \\
\text { used as mouthwash to treat dental and oral } \\
\text { diseases. }\end{array}$ & $\begin{array}{l}\text { Ministry of } \\
\text { Health- } \\
\text { Department of } \\
\text { Traditional } \\
\text { Medicine }\end{array}$ \\
\hline $\begin{array}{l}\text { Rhoeo } \\
\text { spathacea } \\
\text { (Sw.) Stearn }\end{array}$ & $\begin{array}{l}\text { Rhoeo, } \\
\text { Bangka- } \\
\text { bangkaan }\end{array}$ & $\begin{array}{l}\text { The decoction of the leaves is taken orally on } \\
\text { a daily basis to cure cancer although there is } \\
\text { no existing scientific evidence. }\end{array}$ & $\begin{array}{l}\text { Rosales-Reyes } \\
\text { et al, } 2008\end{array}$ \\
\hline $\begin{array}{l}\text { Senna alata } \\
\text { (L.) Robx. }\end{array}$ & Asunting & $\begin{array}{l}\text { Leaf infusion can cure cough while the } \\
\text { decoction is effective against eczema. }\end{array}$ & Kurian, 2010 \\
\hline $\begin{array}{l}\text { Solanum } \\
\text { melongena } \\
\text { L. }\end{array}$ & $\begin{array}{l}\text { Eggplant, } \\
\text { Talong }\end{array}$ & $\begin{array}{l}\text { The decoction of leaves is used to treat sores } \\
\text { and as an astringent for haemorrhage from } \\
\text { the bladder and haemorrhagic fluxes. }\end{array}$ & $\begin{array}{l}\text { Quisumbing, } \\
1978\end{array}$ \\
\hline
\end{tabular}

\section{Preparation of Leaf Samples and Microscopy}

Whole leaf clearing technique using the method of Cote (2009) was done for ease in observation of the crystals. In leaf clearing, much of the protoplasmic materials in the leaf is removed by chemical treatment making the leaf uniformly transluscent and easier to study. The fresh leaf samples were placed in commercial bleach (sodium hypochlorite) for 5-10 minutes and washed three times in $30 \mathrm{~mL}$ distilled water for at least 10 minutes each. To confirm the chemical component of the crystals, the cleared samples were treated with $5 \%$ acetic acid for 24 hours. The solution dissolves calcium carbonate and phosphate but not oxalates. The samples were washed again three times with distilled water before subjecting them to dehydration process by passing them through an alcohol series $(10 \%, 30 \%, 50 \%$, $75 \%, 85 \%$ and $95 \%$ ethanol), and finally rinsing with tertiary butyl alcohol for at least 10 minutes with shaking. The dehydrated samples were then placed in xylene for 10 minutes with occasional swirling.

The cleared samples were mounted on a glass slide with Canada balsam and viewed under a compound microscope at 400x magnification to observe the crystals. Photographs of the calcium oxalate crystals were taken using a photomicroscope $\left(\right.$ Motic $\left.^{\mathrm{TM}}\right)$.

\section{RESULTS AND DISCUSSION}

\section{Crystal Characteristics}

All the five morphological types of calcium oxalate crystals were observed in the 15 species of medicinal plants examined. These were raphides, druses, styloids, prismatic crystals and crystal sands (Table 1). According to Meric (2009b), the type 
of crystals formed in plants is genetically determined. A species may produce a single crystal type throughout the plant, or multiple types with each specific for a certain organ, or multiple types that may exist within the same organ but in different tissues or regions (Franceschi \& Nakata 2005).

Raphide crystals were present in B. spectabilis, C. fruticosa, I. balsamina and $R$. spathacea although styloids were also observed in C. fruticosa (Figure 3 ). According to Pennisi et al (2001), raphides are the most common type of crystals and sometimes occur along with either druses or styloids. In this study, the most common was the druse type recorded in eight out of the 15 species while only four species formed raphides.

Druses were observed in A. esculentus, A. indica, A. viridis, B. alba, B. orellana, C. variegatum, I. batatas, and J. podagrica (Figure 2). The study of Chairiyah et al (2013) in 'Porang' or Amorphophallus muelleri found that druse crystals had a variety of sizes, types, forms and constituent units. One type, the semi- solid druse has a thick ring in the edge and a very thin structure at the center. The druses of $B$. orellana (Figure 2A) and $I$. batatas (Figure 2B) exhibited this characteristic. Another type is the solid druse which is rosette in form. The entire crystal is not concave in structure like the first type but rounded or spherical in shape. This type was observed in A. esculentus, $A$. indica, A. viridis, B. alba, C. variegatum and $J$. podagrica (Figure $2 \mathrm{C}-\mathrm{H}$ ). Anitha \& Sandhiya (2014) stated that druses provide mechanical strength to the leaf and regulate calcium levels in the tissue. Prismatic crystals were observed in $C$. olitorius and $S$. alata (Figure 4A\&B). Those in $C$. olitorius occurred both in the leaf margin and leaf veins but more along the veins while in S. alata, they were confined to the veins. Clusters of crystal sands were observed only in Solanum melongena (Figure 4C).

Table 2. Type of calcium oxalate crystals present in the medicinal plants species studied

\begin{tabular}{lll}
\hline Family & Species & Crystal Type \\
& & \\
\hline Amaranthaceae & Amaranthus viridis L. & druses \\
Asparagaceae & Cordyline fruticosa (L.) A. Chev. & raphides, styloids \\
Balsaminaceae & Impatiens balsamina L. & raphides \\
Basellaceae & Basella alba L. & druses \\
Bixaceae & Bixa orellana L. & druses \\
Commelinaceae & Rhoeo spathacea (Sw.) Stearn & raphides \\
Convolvulaceae & Ipomoea batatas (L.) Lam & druses \\
Euphorbiaceae & Acalypha indica L. & druses \\
& Codiaeum variegatum (L.) A. Juss. & druses \\
Fabaceae & Jatropha podagrica Hook. & druses \\
Malvaceae & Senna alata (L.) Robx. & prismatic crystals \\
Nyctaginaceae & Abelmoschus esculentus (L.) Moench & druses \\
Solanaceae & Bougainvillea spectabilis Wild. & raphides \\
Tiliaceae & Solanum melongena L. & crystal sands \\
\hline
\end{tabular}


Occurrence and variation of calcium oxalate crystals

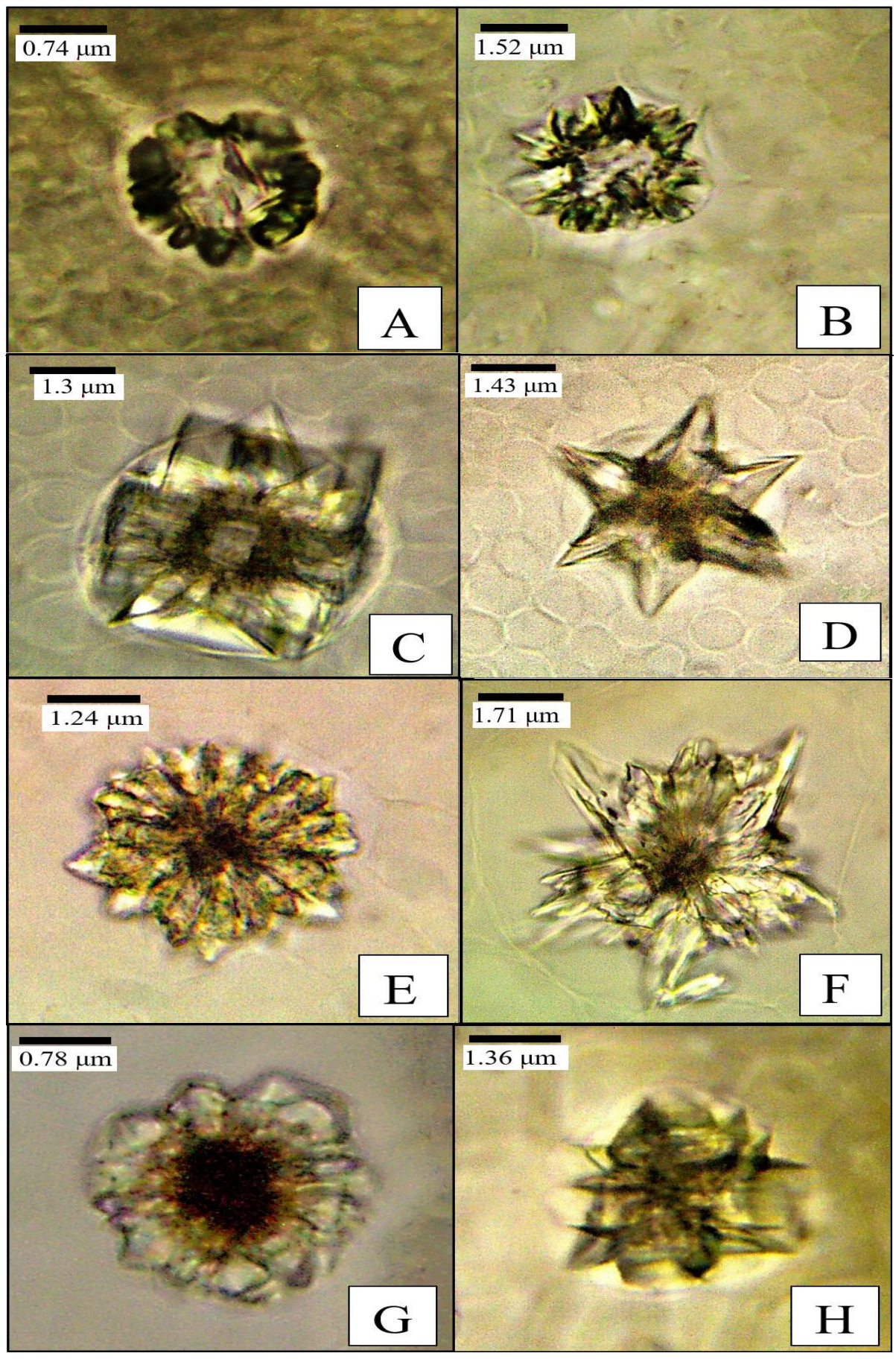

Figure 2A-H. Druses in: A. Bixa orellana, B. Ipomoea batatas, C. Abelmoschus esculentus, D. Acalypha indica, E. Amaranthus viridis, F. Basella alba, G. Codiaeum variegatum, H. Jatropha podagrica. Magnification: $400 \mathrm{x}$ 
Capacio \& Belonias

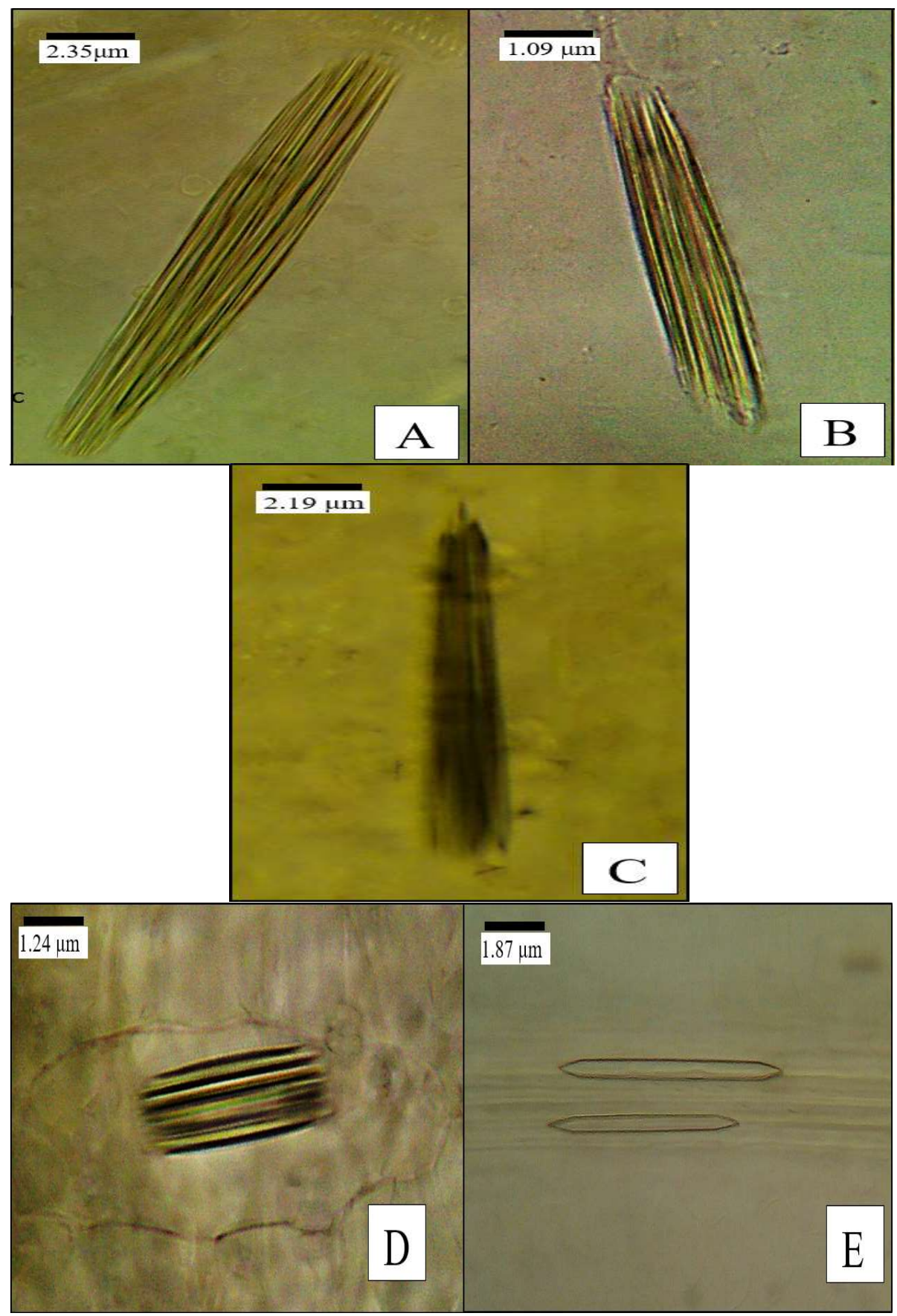

Figure 3A-E. Raphides in: A. Bougainvillea spectabilis, B. Impatiens balsamina, C. Rhoeo spathacea, D. Cordyline fruticosa, E. Styloid crystals in Cordyline fruticosa. Magnification: 400x 
Occurrence and variation of calcium oxalate crystals

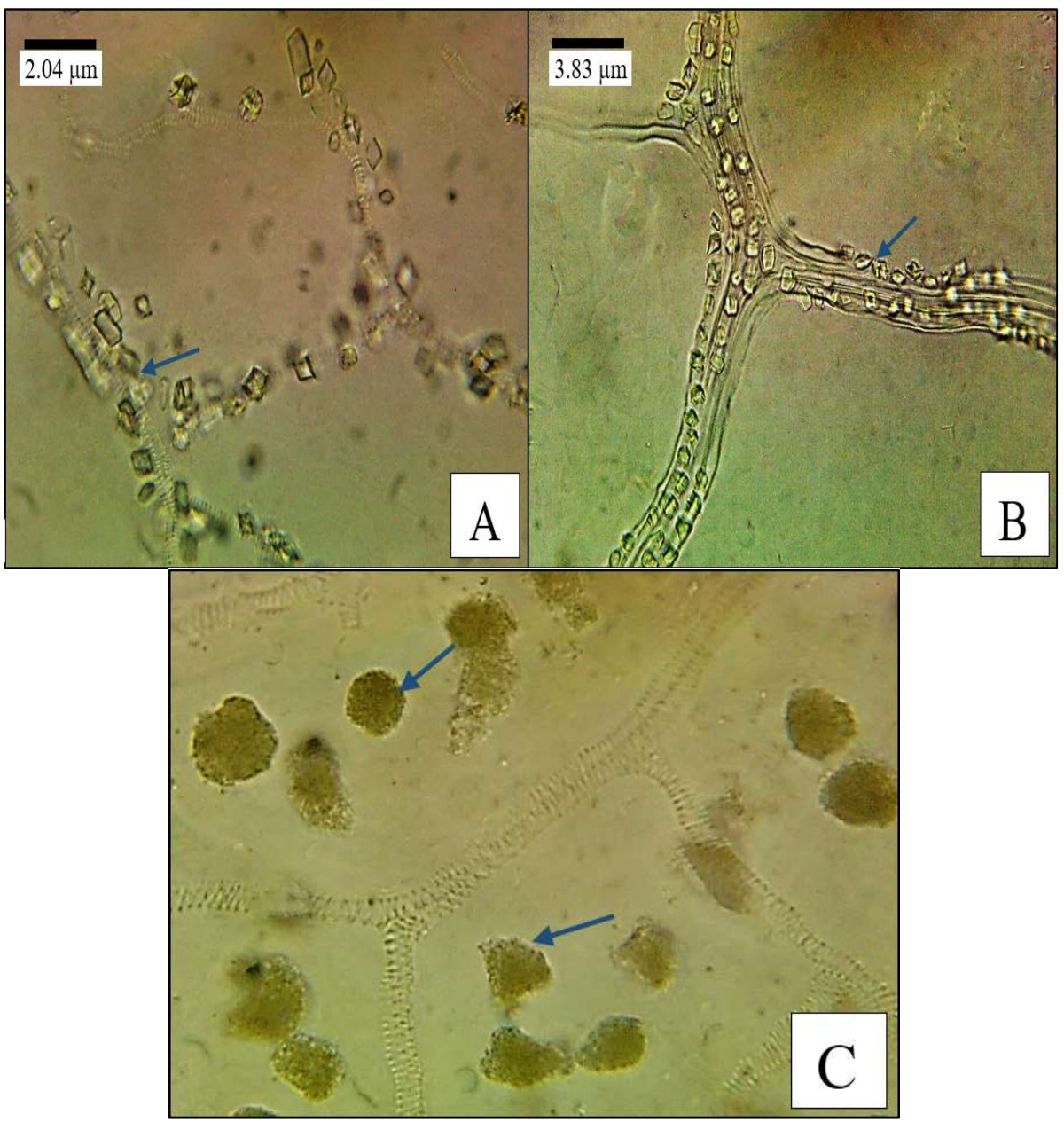

Figure 4. Prismatic crystals in Corchorus olitorius (A) and Senna alata (B); Clusters of crystal sands in Solanum melongena (C)

The density of calcium oxalate crystals differed significantly among species. Three species contained the most number of crystals. $C$. olitorius had the highest density with 13,681 crystals per $\mathrm{mm}^{2}$ leaf area followed by $S$. alata with 12,851 per $\mathrm{mm}^{2}$ and $C$. variegatum with 5,590 per $\mathrm{mm}^{2}$. The rest of the species had lower densities with Rhoeo spathacea having the least with only 30 crystals $/ \mathrm{mm}^{2}$ (Figure 5 ). The overall density of crystals, regardless of type, did not differ significantly between the leaf veins and interveinal regions (Figure 6). Cao (2003) found that the total $\mathrm{CaOx}$ crystal density in an unfurled leaf of the three Dieffenbachia cultivars 'Carina', 'Rebecca', and 'Star bright' were 9,470, 4,391, and 5,942 crystals per $\mathrm{cm}^{2}$, respectively. In the study of Seker et al (2016), the druses, raphides and prismatic crystals in the petioles of Vitis vinifera were 140,41 and 9 per $\mathrm{mm}^{2}$, respectively. 
Capacio \& Belonias

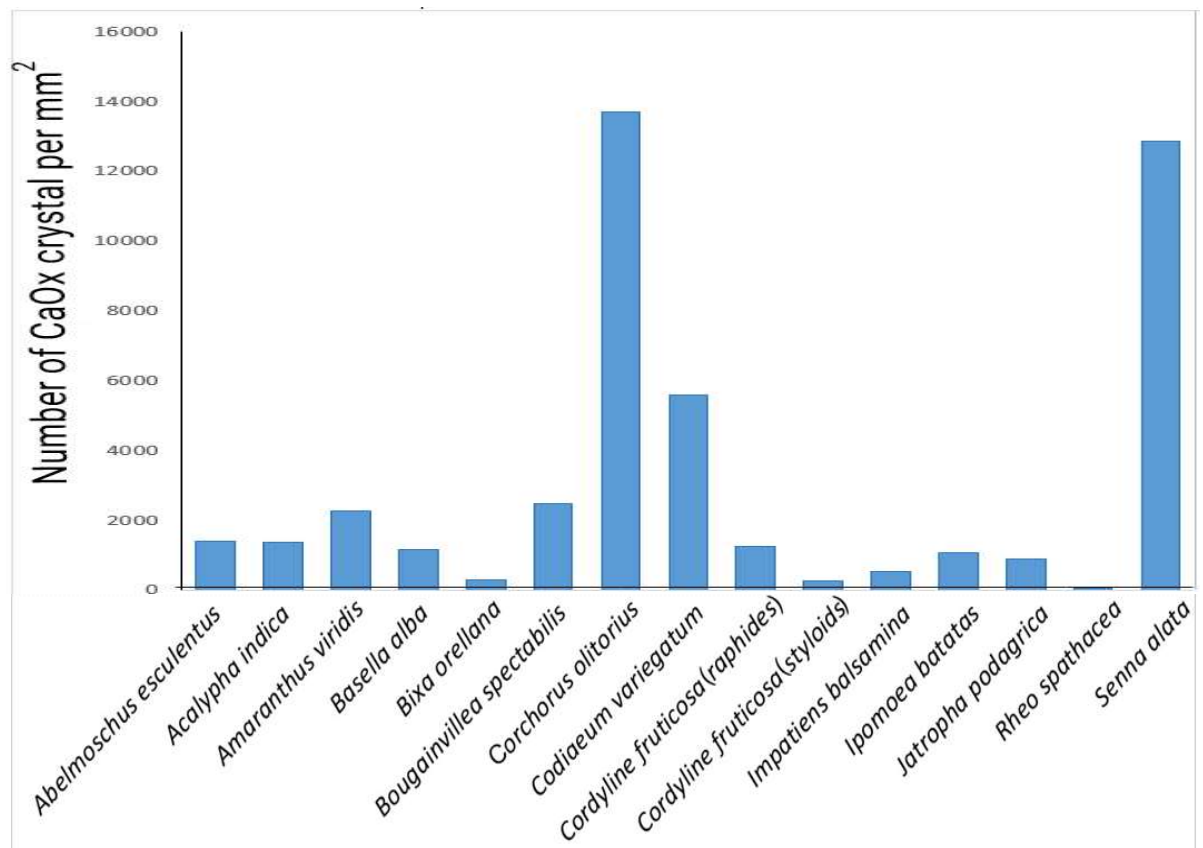

Figure 5. Mean density (no. of crystals $/ \mathrm{mm}^{2}$ ) of calcium oxalate crystals in the leaves of different medicinal plant species

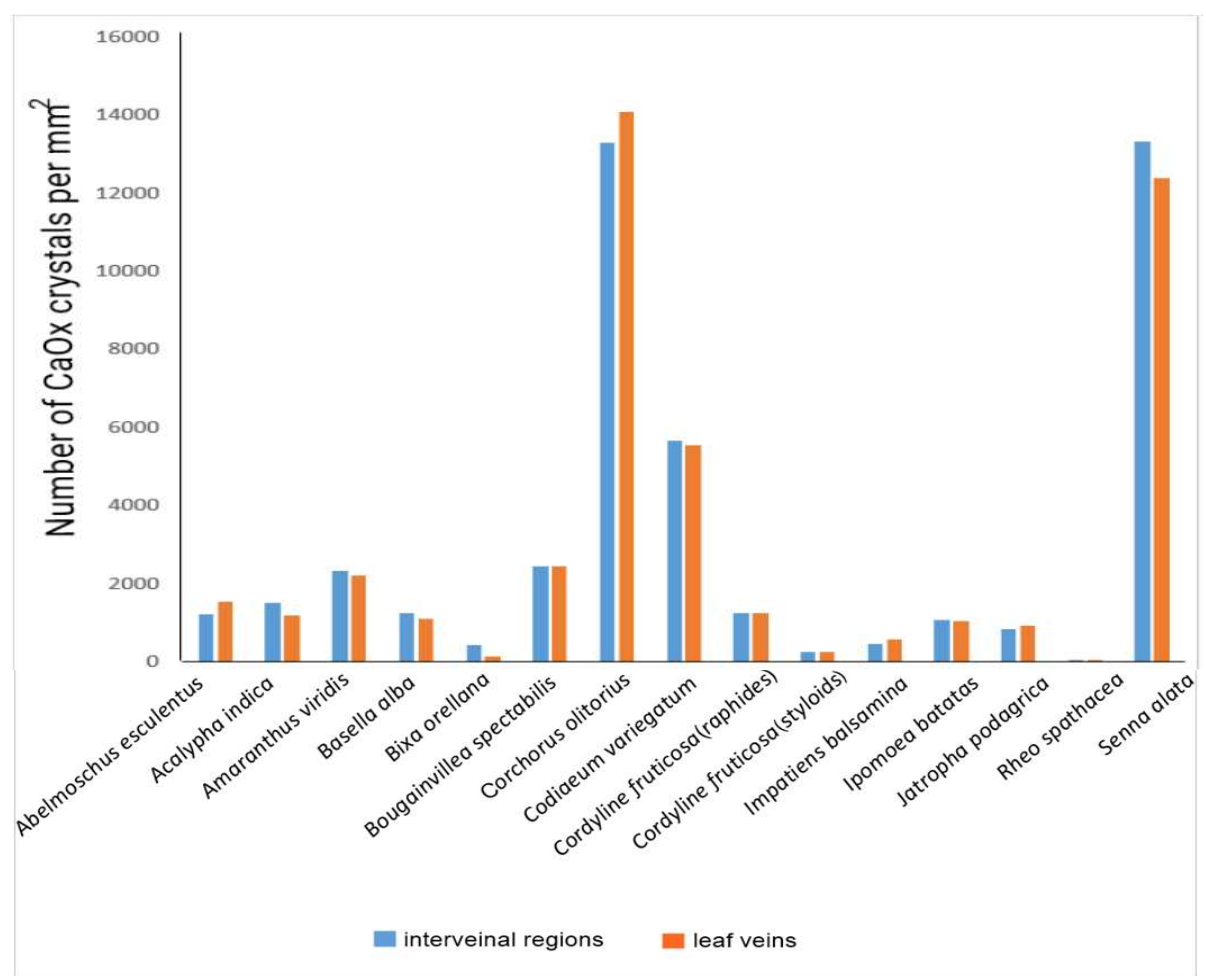

Figure 6. Comparative mean density (no. of crystals $/ \mathrm{mm}^{2}$ ) of calcium oxalate crystals in the leaf veins and interveinal regions of the leaves 
Occurrence and variation of calcium oxalate crystals

Franceschi and Nakata (2005) said that the differences in the density and distribution of the $\mathrm{CaOx}$ crystals within a plant are highly variable among species. This is probably due to the variety of functions of these crystals and also the timing of when these functions need to be expressed with respect to development or physiological maturity. Furthermore, the distribution of crystals in the plant is constant within a species which makes them an important taxonomic character.

The sizes of the different crystal types varied with species (Figure 7). B. spectabilis had the longest raphides measuring $175.81 \mu \mathrm{m}$ followed by $R$. spathacea, I. balsamina and C. fruticosa with raphides measuring $128.64 \mu \mathrm{m}$, $56.53 \mu \mathrm{m}$, and $41.78 \mu \mathrm{m}$, respectively (Figure $7 \mathrm{~A}$ ). Sizes of druses did not vary significantly between the margin and the midvein regions but differed significantly among species (Figure 7B). The druses of $B$. alba were the largest at $76.79 \mu \mathrm{m}$ diameter followed by those in $A$. esculentus, $A$. indica, $A$. viridis and J. podagrica with $51.51 \mu \mathrm{m}, 50.26 \mu \mathrm{m}, 40.56 \mu \mathrm{m}, 38.25 \mu \mathrm{m}$, respectively. Meanwhile, $B$. orellana had the smallest druses having an average diameter of only $16.72 \mu \mathrm{m}$. The prismatic crystals of $C$. olitorius were the biggest having a surface area of at $48.78 \mu \mathrm{m}^{2}$ compared to those of $S$. alata which had only $23.47 \mu \mathrm{m}^{2}$. The sizes of the crystal sands in $S$. melongena could not be determined as they were too minute to measure in the compound microscope.

Anitha and Sandhiya (2014) reported that CaOx crystals in Amaranthus gangeticus leaves were large druses measuring $22.1 \mu \mathrm{m}$ and Cissus quadrangularis had rosette crystals of $25 \mu \mathrm{m}$, druses of $15.4 \mu \mathrm{m}$ and raphides of $69.7 \mu \mathrm{m}$. Chairiya et al (2013) pointed out that Porang (Amorphophallus muelleri Blume) leaves had druses measuring $20-60 \mu \mathrm{m}$ and prismatic crystals of $2-10 \mu \mathrm{m}$. The prismatic crystals in Dieffenbachia seguine had an average size of $48 \mu \mathrm{m}$ and about $65 \mu \mathrm{m}$ in Caladium bicolor and Xanthasoma sp. The styloids had sizes ranging from $2-10 \mu \mathrm{m}$ and $11-13 \mu \mathrm{m}$. The difference in sizes of $\mathrm{CaOx}$ crystals observed in this present study could be due to genetic differences especially that the 15 species used in this study belong to different families. Franceschi and Nakata (2005) mentioned that a combination of genetic and environmental factors play a role in defining $\mathrm{CaOx}$ crystal amount, shape and size including its function. Sizes of $\mathrm{CaOx}$ crystals vary tremendously and are responsive to the function of the cell type in which the crystals were formed, the amount of available $\mathrm{Ca}$, and other environmental factors such as light and $\mathrm{pH}$. 
Capacio \& Belonias
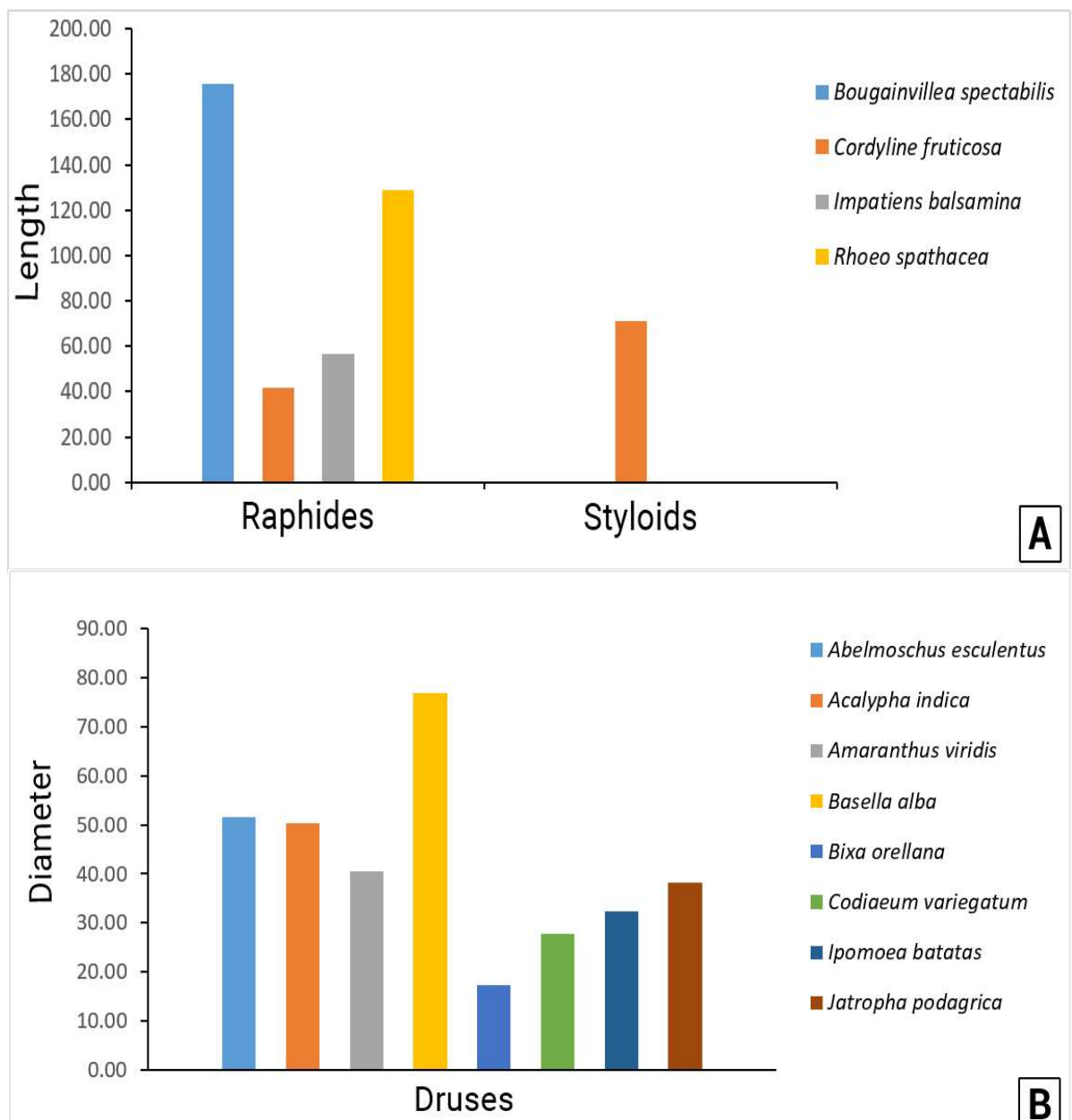

Abelmoschus esculentus

Acalypha indica

Amaranthus viridis

Basella alba

Bixa orellana

- Codiaeum variegatum

- Ipomoea batatas

- Jatropha podagrica

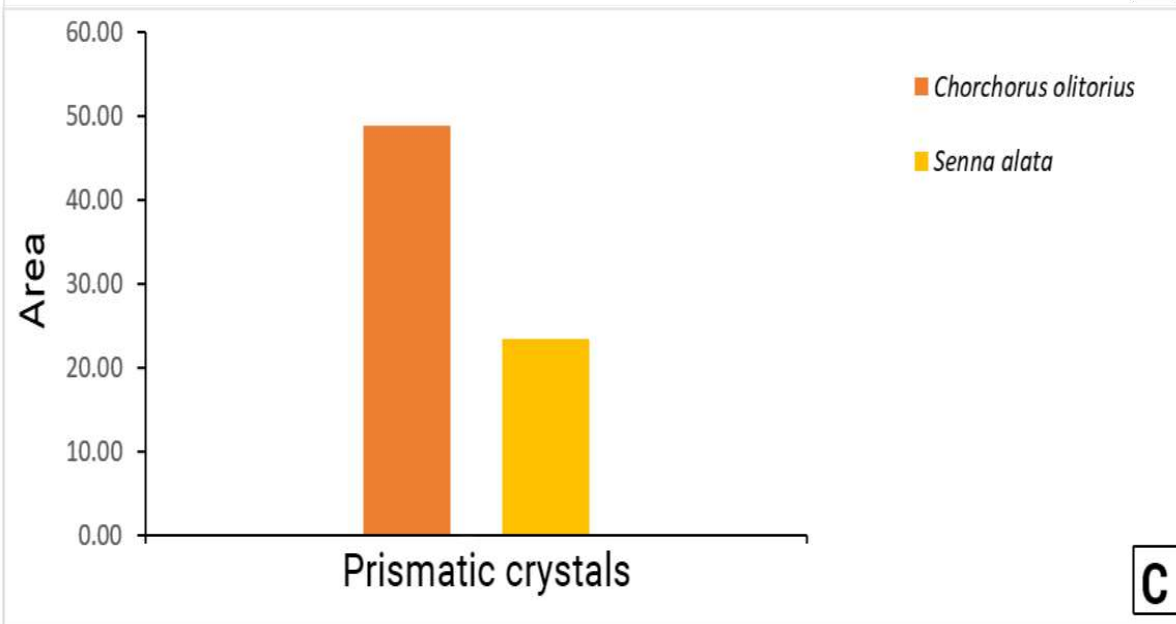

Figure 7A-C. Length of raphides and styloids in $\mu \mathrm{m}(\mathrm{A})$, diameter of druses in $\mu \mathrm{m}(\mathrm{B})$, area of prismatic crystals in $\mu \mathrm{m}^{2}(\mathrm{C})$ in different medicinal plant species 
Occurrence and variation of calcium oxalate crystals

\section{Application in Plant Identification}

As earlier presented in Table 2, fourteen out of the 15 species produced only one type of crystals. Raphides are produced in $I$. balsamina, $R$. spathacea and $B$. spectabilis, prismatic crystals in S. alata and C. olitorius, and crystal sands in S. melongena. The rest of the species produced druses, except for $C$. fruticosa which formed two crystal types; raphides and styloids. The size, location and density of the crystals also varied with species. Thus, the type and other characteristics of the crystals can therefore be used to aid in the identification or confirmation of the medicinal plant species present in various crude herbal preparations. Nowadays, crude herbal preparations usually in the form of tablets, capsules, powdered form, finely chopped or even whole dried leaves are flooding the market, in pure or in mixed forms, some of which do not have a Food and Drug Administration (FDA) approval. Many are even imported illegally from other countries. Consumers need to be assured that they get their money's worth and that they are not taking fake and/or adulterated products. One potential way to help check the authenticity of the claimed plant components of the product is through microscopic examination of the calcium oxalate crystals present.

\section{Potential Health Risks}

Consuming heavy loads of $\mathrm{CaOx}$ crystals have been reported to have adverse effects on health. Excessive consumption of these crystals by animals, including humans, may induce renal problems due to formation of renal stones (Odufuwa et al 2014). An excess of raphides, in conjugation with cytotoxic compounds can cause food poisoning and even death. CaOx crystals contribute up to $70 \%$ to $75 \%$ of kidney stone composition and are present in either mono, di and tri-hydrate forms. The monohydrate form is the least soluble and readily attaches to the surface of the renal tubule to form kidney stones (Knight \& Walter 2003). In medicine, dietary control is frequently recommended in the treatment of kidney stones (Tripathi et al 2015). Ruan et al (2013) stated that patients with kidney stones must control their dietary oxalate intake to less than 40-50mg per day.

In this study, it was found that $C$. olitorius, $S$. alata and $C$. variegatum contained the highest density of crystals which means they could potentially contain high loads of oxalates, and when these plants are consumed in large quantities, oxalate content may reach harmful levels. Although B. spectabilis and $R$. spathacea, were the two lowest in crystal density, the crystals that they form are large raphides which have more harmful effects compared to the other crystal types. Aside from the potentially higher oxalate content due to their large size, their structure resembles long needles that are pointed at both ends which can cause irritation and inflammation of body tissues. In fact, the antiherbivore property of leaves against chewing insects and other grazing animals has usually been associated with the presence of raphides (Doege et al 2003, Ruiz et al 2002, Eco 2016). On the other hand, $B$. orellana produced the smallest druses and was second to $R$. spathacea in having the least number of crystals, which could imply that $B$. orellana is the safest among the 15 species studied. Meanwhile, although $C$. fruticosa produced the shortest raphides, it also contained a second type of crystals, the styloids, and that the combined oxalate content of both crystals may be unsafe too. 
The aforementioned discussion of potential health risks is only speculative considering that actual laboratory quantification of the calcium oxalate content of the plants was not undertaken in the present study.

\section{CONCLUSION}

Calcium oxalate crystals are produced in all 15 species of medicinal plants studied. Druses were the most common type produced in eight out of the 15 species while prismatic and crystal sands were the least common. The crystals were formed in both the leaf veins and in the interveinal regions of the leaf. Chorchorus olitorius, Senna alata and Codiaeum variegatum had the highest density of crystals. Bougainvillea spectabilis and Rhoeo spathacea produced the largest crystals, but in least densities. Considering the reported adverse effects of heavy loads of $\mathrm{CaOx}$ crystals to human health such as formation of renal stones, tissue injury, inflammation and in severe cases, poisoning and death, it would be safe to say that caution should be taken against consumption of large quantities of the leaves of species containing crystals especially those having large-sized crystals or having high density of crystals. However, it is recommended that further studies be conducted to confirm or validate the potential health risks of using the aforementioned species which should include, among others, quantification of the calcium oxalate content per unit weight of leaves in order to establish the safe volume or quantity of leaves to be consumed for each species. Furthermore, characterization of the calcium oxalate crystals of more species of medicinal plants is suggested in order to gradually establish the crystal profile of each and every medicinal plant, especially those found in the Philippines.

\section{REFERENCES}

Anitha R and Sandhiya T. 2014. Occurrence of calcium oxalate crystals in the leaves of medicinal plants. International Journal of Pharmacognosy, 1(6):389-393

Cao H. 2003. The distribution of calcium oxalate crystals in genus Dieffenbachia Schott. and the relationship between environmental factors and crystal quantity and quality.MS thesis, University of Florida, Gainesville, Florida, USA

Chairiya N, Harijati N \& Mastuti R. 2013. Variation of calcium oxalate (CaOx) crystals in Porang (Amorphophallus muelleri Blume). American Journal of Plant Sciences, 4(9):1765-1773

Cote GG. 2009. Diversity and distribution of idioblast producing calcium oxalate crystals in Dieffenbachia seguine (Araceae). American Journal of Botany, 96(7):1245-1254

Doege SJ. 2003. The role of natural calcium oxalate crystals in plant defense against chewing insects. Inquiry, 4:88-94

Eco KO. 2017. Calcium Oxalate Crystal Density in Leaves of Colocasia esculenta (L.) Schott (Araceae) in Response to Herbivory and Water Availability. Annals of Tropical Research, 39(1):54-69

Flores BM. 2001. Herbivory and calcium concentration affect calcium crystal formation in leaves of Sida (Malvaceae). Annals of Botany, 88(3):387-391

Franceschi VR and Nakata PA. 2005. Calcium oxalate in plants: formation and function. Annual Review of Plant Biology, 56:41-71 
Occurrence and variation of calcium oxalate crystals

He H, Bleby TM, Veneklaas EJ, Lambers H \& Kuo J. 2012. Morphologies and elemental compositions of calcium crystals in phyllodes and branchlets of Acacia robeorum (Leguminosea: Mimosoideae). Annals of Botany. Doi: $10.1093 / \mathrm{aob} / \mathrm{mcs} 004$

Ilarsan H, Palmer RG, Imsande J \& Horner HT. 1997. Quantitative determination of calcium oxalate and oxalate in developing seeds of soybean (Leguminosae). American Journal of Botany, 84(8):1042-1046

Knight AP and Walter RG. 2003. Plants Causing Kidney Failure. A guide to plant poisoning of animals in North America. Teton NewMedia, Jackson WY

Konyar ST, Öztürk N \& Dane F. 2014. Occurrence, types and distribution of calcium oxalate crystals in leaves and stems of some species of poisonous plants. Botanical Studies, 55:32. Doi: 10.1186/1999-3110-55-32

Lengsfeld C, Titgemeyer F, Faller G \& Hensel A. Glycosylated compounds from okra inhibit adhesion of Helicobacter pyroli to human gastric mucosa. Journal of Agricultural and Food Chemistry. 2004. 52(6):1495-1503

Malviya N, Jain S \& Malviya S. 2010. Review: Anti-diabetic Potential of Medicinal Plants. Acta Poloniae Pharmaceutica Drug Research, 67(2):113-118

Meric C. 2009a. Calcium oxalate crystals in some species of the Tribe Inuleae (Asteraceae). Acta Biologica Cracoviensia Series Botanica, 51(1):105-110

Meric C. 2009b. Calcium oxalate crystals in Aster squamatus and Bellis perennis (Asteraceae: Asterae). Phytologia Balcanica, 15(2):255-259

Odufuwa TK, Atunnise AK, Olukanni OD \& Salau BA. 2014. Juicing alters oxalates contents in commonly consumed leafy vegetables in Southwest Nigeria. International Journal of Nutrition and Food Sciences, 3(3):183-186

Pennisi SV, Mcconnell DB, Gower LB, Kane ME \& Lucansky T. 2002. Intracellular calcium oxalate crystal structure in Dracaena sanderiana. New Phytologist, 150(1):111-120

Quisumbing E. 1978. Medicinal Plants of the Philippines. Katha Publishing Co., INC. JMC Press INC, Quezon City, Philippines

Reyad-ul-Ferdous M, Shahjahan DMS, Tanvir S \& Mukti M. 2015. Present biological status of potential medicinal plant of Amaranthus viridis: a comprehensive review. American Journal of Clinical and Experimental Medicine, 3(5-1):12-17

Rosales-Reyes T, De La Garza M, Arias-Castro C, Rodriguez-Mendiola M, FattelFazenda S, Arce-Popoca E, Hernandez-Garcia S \& Villa-Triviño S. 2008. Aqueous crude extract of Rhoeo discolor, a Mexican medicinal plant, decreases the formation of liver preneoplastic foci in rats. Journal of Ethnopharmacology, 115(3):381-386

Ruan QY, Zheng XQ, Chen BL, Xiao Y, Peng XX, Leung DWM \& Liu EE. 2013. Determination of total oxalate contents of a great variety of foods commonly available in Southern China using an oxalate oxidase prepared from wheat bran. Journal of Food Composition and Analysis, 32(1):6-11

Ruiz N, Ward D \& Saltz S. 2002. Calcium oxalate crystals in leaves of Pancratium sickenbergeri: constitutive or induced defense. Functional Ecology, 16(1):99-105

Seker SS, Akbulut MK \& Senel G. 2016. Calcium oxalate crystal (CaOx) composition at different growth stages of petiole in Vitis vinifera (Vitaceae). Advanced Studies in Biology, 8(1):1-8

Tomoda M, Shimizu N, Gonda R, Kanari M, Yamada H \& Hikino H. 1989. Anticomplementary and hypoglycemic activity of okra and hibiscus mucilage. Carbohydrate Research, 190(2):323-8 
Tripathi N, Bose C, Das N, Maitra S, Sikdar A \& Khurana S. 2015. Raphides in food-an unsafe menu. Journal of Plant Biochemistry and Physiology, 3:2. Doi:10.4172/23299029.1000143

Umamaheswari A, Shreevidya R \& Nuni A. 2008. In vitro antibacterial activity of Bougainvillea spectabilis leaves extracts. Advances in Biological Research, 2(1-2):1-5

Zhang J, Lu H \& Huang L. 2014. Calciphytoliths (calcium oxalate crystals) analysis for the identification of decayed tea plants (Camellia sinensis L.). Scientific Reports, 4. DOI: $10.1038 /$ srep06703 